\title{
Aktivitas Jus Buah Delima (Punica granatum L.) terhadap Peroksidasi Lipid Darah Tikus yang Diinduksi Parasetamol
}

\author{
Anna Priangani Roswiem ${ }^{1)}$, Heryani' ${ }^{1)}$, Dian Apriliana ${ }^{1)}$ \\ 1)Department Biochemistry,Faculty of Mathematic and Natural Sciences, IPB, Bogor 1661. \\ Email: annap_ros@yahoo.com
}

\begin{abstract}
Pomegranate (Punica granatum L.) has been reported to have the higher antioxidant activities than other medicinal plants. The antioxidant activities decrease blood lipid peroxidation or tiobarbituric acid reacting substances (TBARS). The aim of this study was to investigate pomegranate juice activities against TBARS in rats induced by paracetamol. Fourteen rats were divided into 4 groups. Those were the Normal group (N) induced by aquadest and 3 treatment groups such as the positive control (PC), the negative control (KN), and the pomegranate juice group (JUS) induced by paracetamol (500 mg/kgBW) during 34 days. After 17 days, the groups induced by paracetamol, such as the (PC) group of treatment induced by Cursil70 (13,3 $\mathrm{mg} / \mathrm{kgBW}$ ), pomegranate juice (JUS) group induced by pomegranate juice using the doses of $500 \mathrm{mg} / \mathrm{kgBW}$, but negative control group (KN) still induced by paracetamol (500 mg/kgBW). Blood lipid peroxide was reacted by thiobarbituric acid (TBA)1\% and analysed by spectrophotometer using $\lambda 352 \mathrm{~nm}$. The negative control (KN) which was induced by Paracetamol as long as 34 days increased TBARS levels of 120,66\%. The PC and pomegranate juice (JUS) using the doses $500 \mathrm{mg} / \mathrm{kg} \mathrm{BW}$ decreased TBARS levels of 8,14\% and $54,79 \%$, respectively.
\end{abstract}

Key words:Pomegranate, Punica granatum L., blood lipid peroxide, paracetamol

\section{PENDAHULUAN}

Buah delima atau yang dikenal dengan sebutan buah Pomegranat, memiliki beberapa senyawa aktif yaitu alkaloid, flavonoid, saponin, tanin, dan triterpenoid. Malik et al. (2005) melaporkan bahwa buah delima mengandung dua tipe komponen polifenol yaitu flavonoid (antosianin) dan tanin terhidrolisis yang mempunyai aktivitas antioksidan dan menurut Aviram et al. (2000) aktivitas antioksidan buah delima dilaporkan lebih tinggi dibandingkan aktivitas antioksidan anggur merah dan teh hijau. Selain itu, Aviram et al. (2000) menyatakan bahwa antioksidan berpotensi dalam penurunan peroksidasi lipid.

Heryani (2010) melaporkan bahwa fraksi polifenol buah delima mampu menurunkan konsentrasi lipid peroksida serum tikus yang diinduksi parasetamol. Masa kini banyak diperjualbelikan jus buah buahan, antara lain jus buah delima. Mengingat masyarakat akan lebih mudah mengonsumsi buah delima dalam bentuk jus buahnya, maka tujuan penelitian ini adalah untuk menguji aktivitas jus buah delima terhadap peroksidasi lipid darah tikus yang diinduksi parasetamol dengan dosis $500 \mathrm{mg} / \mathrm{kgBB}$. Hipotesis penelitian ini adalah jus buah delima dapat menurunkan kadar lipid peroksida darah tikus yang diinduksi parasetamol. Potensi yang diperoleh akan dibandingkan dengan Cursil 70 (obat hepatitis) dengan dosis $13,3 \mathrm{mg} / \mathrm{kgBB}$. Metode yang digunakan untuk mengukur konsentrasi lipid peroksida serum tikus adalah metode asam tiobarbiturat (TBA) dengan menggunakan spektrofotometer pada $\lambda 532 \mathrm{~nm}$ (Yagi, 1994). Hasil penelitian ini diharapkan dapat menambah informasi potensi jus buah delima sebagai hepatoprotektor dan dapat dijadikan obat hepatitis alternatif bagi penderita hepatitis.

\section{METODE PENELITIAN}

Bahan

Penelitian dilakukan di Laboratorium Biokimia Departemen Biokimia FMIPA-IPB. Bahan bahan yang digunakan dalam penelitian ini adalah tikus putih jantan galur Sprague Dawley (dari Pusat Studi Biofarmaka - IPB) dengan kondisi sehat berumur 8 minggu dan berat 140$180 \mathrm{~g}$, pakan standar (Indofeed, Indonesia), buah 
delima (dari Lampung) dan Cursil 70 (Sanmol, Indonesia). Selain itu beberapa pereaksi yang digunakan adalah 1,1,3,3-tetrametoksipropana 6 $\mathrm{M}, \mathrm{H}_{2} \mathrm{SO}_{4} 1 / 12 \mathrm{~N}$, TBA $1 \% \mathrm{~b} / \mathrm{v}, \mathrm{H}_{2} \mathrm{O}_{2}$, asam asetat, piridin dan $\mathrm{HCl}$.

Alat

Alat-alat yang digunakan dalam
penelitian ini adalah neraca analitik, spektrofotometer UV-Vis Genesys type, vortex, sentrifus klinis, mikrosentrifus, $\mathrm{pH}$ indicator, dan $\mathrm{pH}$ meter. Peralatan lainnya adalah labu ukur, labu Erlenmeyer, pipet tetes, pipet Mohr, pipet mikro dan cawan porselin.

\section{ProsedurPenelitian}

Penelitian ini dilaksanakan dalam beberapa tahap kegiatan, yaitu penetapan kadar air, adaptasi hewan coba, perlakuan hewan coba, pengukuran konsentrasi lipid peroksida, serta analisis statistika. Sebelumnya dilakukan preparasi sampel, yaitu pembuatan jus buah delima.

\section{Penetapan Kadar Air (AOAC 1995)}

Cawan porselin dikeringkan pada suhu $105^{\circ} \mathrm{C}$ selama 30 menit, lalu dikeringkan dalam desikator dan ditimbang. Kadar air ditetapkan dengan cara menimbang $5 \mathrm{~g}$ bulir buah delima di dalam cawan porselin kemudian dipanaskan pada suhu $105^{\circ} \mathrm{C}$. Kemudian, dilakukan pendinginan dalam desikator. Setelah 2 jam, bobot sampel dalam cawan porselin ditimbang. Selanjutnya penimbangan dilakukan setiap 30 menit hingga bobot konstan atau berbeda $\leq 0,0003$ g. Penetapan kadar air dilakukan sebanyak 3 kali. Kadar air dihitung dengan menggunakan rumus :

$$
\begin{aligned}
& \text { Kadarair }=\underline{\mathrm{W}}-\left(\mathrm{W}_{1}-\mathrm{W}_{2}\right) \\
& \mathrm{W}=\text { Bobot sampel }(\mathrm{g}) \\
& \left.\mathrm{W}_{1}=\text { Bobot (cawan }+ \text { sampel }\right)
\end{aligned}
$$

setelah di oven

$$
\mathrm{W}_{2}=\text { Bobot cawan kosong }
$$

\section{Perlakuan Hewan Coba}

Hewan coba yang digunakan adalah

tikus jantan galur Sprague Dawley. Hewan percobaan berjumlah 14 ekor yang dikelompokkan menjadi 4 kelompok. Tikus dikandangkan secara individu beralaskan sekam kayu. Tikus diberi pakan standar 20 g/ekor/hari pada tahap adaptasi dan ditingkatkan menjadi 25 g/ekor/hari pada tahap perlakuan dan air minum secara ad libitum. Sebelum perlakuan, tikus diadaptasi selama 17 hari untuk menyeragamkan cara hidup dan pola makan dengan pakan standar dan air minum ad libitum. Tikus kelompok 1 (4 ekor) merupakan kelompok normal (N) yang hanya diberi pakan standar dan air minum ad libitum selama penelitian dan dicekok akuades pada hari ke-18 hingga hari ke-34 perlakuan. Kelompok II (3 ekor) atau kontrol positif (KP) yang menggunakan Cursil 70 (obat hepatitis) dengan dosis 13,3 mg/kg BB dari hari ke-18 hingga hari ke-34. Kelompok III (3 ekor) adalah kelompok negatif $(\mathrm{KN})$ yang dicekok parasetamol dengan dosis $500 \mathrm{mg} / \mathrm{kg}$ BB pada hari ke-0 hingga ke-34. Kelompok IV (4 ekor) yang merupakan kelompok perlakuan yang dicekok dengan jus buah delima (JUS) pada konsentrasi $500 \mathrm{mg} / \mathrm{kg}$ BB dari hari ke-18 hingga hari ke-34. Kelompok II-IV secara bersamaan dicekok parasetamol $500 \mathrm{mg} / \mathrm{Kg} \mathrm{BB}$ dari hari ke-0 hingga hari ke-34.

\section{Pengukuran Konsentrasi Lipid Peroksida Serum (Yagi, 1994)}

Pengambilan Serum Sampel. Darah tikus diambil dari pembuluh vena ekor (hari ke-0 dan ke-18). Sebelum darah diambil, tikus dipuasakan minimal 12 jam. Sampel darah yang diperoleh pada vial didiamkan pada kotak berisi es dan disimpan pada lemari pendingin selama semalam. Serum dipisahkan dengan sentrifugasi 3000 rpm selama 15 menit.

Persiapan Kurva Standar. Larutan stok pereaksi 1,1,3,3 tetrametoksi-propana (TMP) $6 \mathrm{M}$ diencerkan menjadi 0,$9 ; 1,8 ; 2,7 ; 3,6 ; 4,5$; dan 6 $\mathrm{mL}$, lalu masukkan ke dalam tabung reaksi dan ditambahkan $1,0 \mathrm{~mL}$ TBA $1 \% \mathrm{~b} / \mathrm{v}$ dalam pelarut asam asetat $50 \% \mathrm{v} / \mathrm{v}$. Tahap selanjutnya tabung diinkubasi pada suhu $95^{\circ} \mathrm{C}$ selama 60 menit dan didinginkan pada suhu kamar. Tabung yang telah dingin ditambah 1,0 mL air destilasi serta $5 \mathrm{~mL} n$ butanol:piridin 15:1(v/v). Tabung ini selanjutnya dihomogenkan dengan menggunakan vortex dan sentrifugasi pada kecepatan $3000 \mathrm{rpm}$ selama 15 menit. Lapisan atas (fasa organik) diambil dan diukur absorbansinya dengan spektrofotometer pada panjang gelombang $532 \mathrm{~nm}$.

Pengukuran Sampel. Serum tikus diambil sebanyak $0,3 \mathrm{~mL}$, kemudian ditambah 1,2 $\mathrm{mL} \mathrm{H}_{2} \mathrm{SO}_{4} 1 / 12 \mathrm{~N}$. Campuran dibiarkan 10 menit, selanjutnya diberi asam fosfotungstat $10 \%$ (v/v) sebanyak 0,15 mL dan diinkubasi pada suhu ruang selama 5 menit. Selanjutnya, campuran tersebut disentrifugasi pada $3000 \mathrm{rpm}$ selama 20 
menit. Supernatan yang telah diperoleh dibuang, sedangkan terhadap peletnya ditambahkan $1,2 \mathrm{~mL}$ $\mathrm{H}_{2} \mathrm{SO}_{4} \quad 0,041 \mathrm{~N}$ dan $0,15 \mathrm{~mL}$ asam fosfotungstat $10 \%$, kemudian disetrifus lagi selama 15 menit. Endapan yang diperoleh disuspensikan dalam 2,0 $\mathrm{mL}$ akuades. Prosedur selanjutnya sama seperti yang dilakukan pada larutan standar (setengah resep). Sebelum penambahan $5 \mathrm{~mL}$ campuran $n$ butanol:piridin pada sampel, dilakukan penambahan $\mathrm{HCl}$ sampai $\mathrm{pH}-$ nya berkisar 1,6-1,7.

4. Analisis Data (Myers \& Milton 1991)

Rancangan percobaan. Data bobot badan dianalisis dengan menggunakan perangkat lunak SPSS Statistical Data Analysis Seri 17. Data konsentrasi lipid peroksida yang diperoleh diuji dengan Analisis of Variance (ANOVA) pada tingkat kepercayaan $95 \%$ dan taraf $\alpha=0,05$, menggunakan perangkat analysis system (SAS). Uji lanjut yang digunakan adalah uji Tukey. (Myer \& Milton, 1991).

\section{HASIL PENELITIAN}

Sampel buah delima yang digunakan adalah delima matang yang berasal dari Lampung, Indonesia. Kadar air buah delima segar yang diperoleh adalah $83,11 \pm 0,07 \%$.

Seluruh hewan coba sebelumnya dilakukan adaptasi selama 17 hari. Selama tahap adaptasi, tikus hanya diberi pakan standar dan air minum ad libitum serta dilakukan penimbangan bobot badan secara berkala setiap hari. Pakan standar yang digunakan diperoleh dari PT. Indofeed dengan komposisi yang tidak berbeda jauh dengan normal laboratory diet (Tabel 1). Secara keseluruhan semua tikus mengalami peningkatan bobot badan sebesar $37,81 \%$. Bobot badan tikus rata-rata pada awal adaptasi sebesar $161,88 \pm 7,92 \mathrm{~g}$, sedangkan pada akhir adaptasi sebesar 223,08 \pm 5,12 g (data tidak di lampirkan).

Tabel 1.Komposisi pakan standar tikus

\begin{tabular}{|c|c|c|}
\hline $\begin{array}{l}\text { Komposisi } \\
\text { laboratory }\end{array}$ & $\begin{array}{c}\text { PT. Indofeed } \\
(\%)\end{array}$ & Normal \\
\hline $\begin{array}{l}\text { Protein kasar } \\
21\end{array}$ & & 18 \\
\hline $\begin{array}{l}\text { Lemak } \\
5\end{array}$ & & 6 \\
\hline $\begin{array}{l}\text { Serat kasar } \\
4\end{array}$ & & 6 \\
\hline Kadar abu & & 8 \\
\hline
\end{tabular}

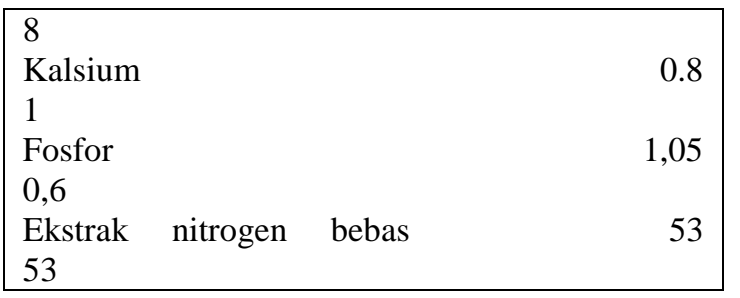

* Sumber: Anila \& Vijayalakshmi (2003)

Setelah adaptasi percobaan dilanjutkan selama 34 hari. Tujuh belas hari pertama, semua kelompok kecuali kelompok normal (N), dicekok parasetamol dengan dosis $500 \mathrm{mg} / \mathrm{kg} \mathrm{BB}$, dengan tujuan untuk meningkatkan konsentrasi lipid peroksida serumnya. Dari hari ke-18 sampai dengan hari ke-35, kelompok (KP) dicekok Cursil 70 dengan dosis 13,3 mg/kgBB; kelompok (KN) tetap dicekok parasetamol $500 \mathrm{mg} / \mathrm{kg} \mathrm{BB}$, dan kelompok (JUS) dicekok jus buah delima dengan dosis $500 \mathrm{mg} / \mathrm{kg}$ BB. Sedangkan kelompok N tetap dicekok akuades.

Konsentrasi Lipid peroksida serum tikus selama 34 hari percobaan terlihat pada gambar 1 berikut.

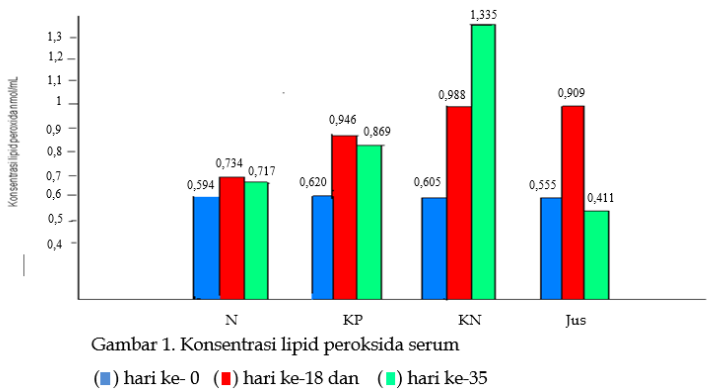

Dari gambar-1, setelah semua tikus diadaptasi, rata-rata konsentrasi lipid peroksida atau TBARS serum pada hari ke-0 untuk semua tikus adalah 0,594 $\pm 0,02 \mathrm{nmol} / \mathrm{ml}$ (Lampiran 1). Dari hari ke-0 sampai dengan hari ke-18, kelompok KP, kelompok KN, dan kelompok jus buah delima (JUS) dicekok parasetamol dengan dosis $500 \mathrm{mg} / \mathrm{kgBB}$, sedangkan kelompok $\mathrm{N}$ dicekok akuades. Konsentrasi TBARS pada hari ke-18 mengalami peningkatan yang signifikan dengan persentase yang berbeda pada tiap kelompok. Konsentrasi TBARS kelompok KP, N, $\mathrm{KN}$, dan jus buah delima (JUS) meningkat berturut-turut sebesar 52,58\%, 23,57\%, 63,31\% dan $63,78 \%$ dari konsentrasi TBARS hari ke-0. 
Setelah peningkatan konsentrasi TBARS, percobaan dilanjutkan hingga hari ke-34 dengan perlakuan yang berbeda pada tiap kelompok. Konsentrasi TBARS pada hari ke-35 (34 hari percobaan) dari kelompok N, KP, dan jus buah delima (JUS) menurun sebesar 2,25\% (untuk kelompok N); 8,14\% (untuk kelompok KP), dan $54,79 \%$ untuk kelompok jus buah delima (JUS) dari konsentrasi TBARS pada hari ke-18. Untuk kelompok KN, konsentrasi TBARSnya tetap meningkat sebesar $35,12 \%$ dari konsentrasi TBARS hari ke-18 (atau meningkat sebesar $120,66 \%$ dari konsentrasi TBARS pada hari ke$0)$.

Dari hasil tersebut, pemberian jus buah delima sebesar $500 \mathrm{mg} / \mathrm{kgBB}$ dapat menurunkan kadar lipid peroksida tikus yang diinduksi parasetamol dengan dosis $500 \mathrm{mg} / \mathrm{kgBB}$. Dengan perkataan lain jus buah delima dapat berfungsi sebagai antioksidan yang akan menurunkan kadar lipid peroksida.

\section{PEMBAHASAN}

Kadar air buah delima pada penelitian ini tidak berbeda nyata dengan hasil yang dilaporkan oleh Al-Maiman dan Ahmad (2002), bahwa kadar air sari buah (JUS) delima matang sebesar 83,65 $\pm 0,4 \%$. Kadar air sampel merupakan nilai yang relatif, bergantung pada ukuran, kematangan buah, tempat tumbuh, dan kondisi lainnya yang dapat mempengaruhi perbedaan kadar air serta komponen lainnya (Al-Maiman \& Ahmad, 2002).

Hewan percobaan yang telah diadaptasi selama 17 hari mengalami kenaikan bobot badan. Kenaikan bobot badan ini dipengaruhi oleh tingkat konsumsi pakan dan umur tikus yang berada dalam masa pertumbuhan (mature point), yaitu kurang dari 6 bulan. Umur tikus yang digunakan pada awal adaptasi adalah \pm 2 bulan. Kondisi ini menunjukkan tikus dalam keadaan sehat, tidak ada gangguan pertumbuhan, kalorinya tercukupi, serta tidak adanya zat toksikan dalam pakan (Lu, 2006). Kondisi ini menjadi faktor yang penting agar dapat memperkecil nilai galat percobaan. Perlakuan hewan coba dilanjutkan dengan induksi atau cekok parasetamol dosis tinggi (500 mg/kgBB) selama 34 hari kecuali pada kelompok normal. Gen (1980) menyatakan bahwa pemberian parasetamol dalam dosis berlebih dapat menimbulkan gejala-gejala anoreksia, mual, muntah, serta sakit perut yang terjadi dalam 24 jam pertama, dan dapat berlangsung terus menerus selama satu pekan atau lebih. Gejala-gejala inilah yang menyebabkan nafsu makan hewan coba menurun. Rata-rata bobot badan tikus pada tahap ini meningkat $13,38 \%$ secara nyata dari $223,08 \pm 8,11$ g menjadi $252,92 \pm 6,96 \mathrm{~g}$ (data tidak di lampirkan). Peningkatan bobot badan ini lebih kecil dibandingkan peningkatan bobot badan pada tahap adaptasi. Hal tersebut disebabkan oleh terjadinya stress akibat dari pencekokan parasetamol yang selanjutnya mengakibatkan penurunan nafsu makannya.

Kondisi kesehatan selama tahap adaptasi dapat mempengaruhi konsentrasi lipid peroksida atau TBARS serum. Rataan konsentrasi TBARS pada hari ke-0 untuk semua tikus adalah 0,594 \pm $0,02 \mathrm{nmol} / \mathrm{mL}$. Hasil ini tidak berbeda dengan hasil penelitian Lavenia (2010) yang menunjukkan bahwa rata-rata konsentrasi lipid peroksida serum tikus pada hari ke-0 adalah $0,586 \pm 0,177 \mathrm{nmol} / \mathrm{mL}$. Konsentrasi TBARS pada kelompok N, KP, KN, dan jus buah delima (JUS) berturut-turut adalah 0,594 $\pm 0,02$ $\mathrm{nmol} / \mathrm{mL} ; \quad 0,620 \pm 0,097 \mathrm{nmol} / \mathrm{mL} ; \quad 0,605 \pm$ 0,099 dan 0,555 $\pm 0,025 \mathrm{nmol} / \mathrm{mL}$ (Gambar 1). Secara statistik (data tidak dilampirkan), konsentrasi TBARS tiap kelompok ini tidak berbeda nyata $\left(\mathrm{F}_{\text {hit }}<\mathrm{F}_{\alpha}\right)$ sehingga dapat disimpulkan bahwa keragaman bobot badan tidak selalu mempengaruhi konsentrasi TBARS serum.

Setelah tahap adaptasi, 17 hari selanjutnya tikus dicekok parasetamol dengan dosis 500 $\mathrm{mg} / \mathrm{kgBB}$ kecuali kelompok normal (N). Pemberian parasetamol ditujukan untuk meningkatkan radikal bebas yang dapat menginduksi aktivitas peroksidasi lipid (Muriel et al. 1992). Hasil penelitian menunjukkan konsentrasi TBARS pada hari ke-18 mengalami peningkatan yang signifikan $(\mathrm{p}<0,05)$ dengan persentase yang berbeda pada tiap kelompok. Konsentrasi TBARS kelompok KP meningkat $52,58 \%$ menjadi $0,946 \pm 0,079 \mathrm{nmol} / \mathrm{mL}$, kelompok $\mathrm{N}$ meningkat $23,57 \%$ menjadi $0,734 \pm$ 0,011, nmol/ml, sedangkan pada kelompok KN meningkat $63.31 \%$ menjadi $0,988 \pm 0,047$ $\mathrm{nmol} / \mathrm{mL}$. Konsentrasi TBARS kelompok jus buah delima (JUS) mengalami peningkatan sebesar $63,78 \%$ menjadi $0,909 \pm 0,062 \mathrm{nmol} / \mathrm{mL}$.

Peningkatan konsentrasi lipid peroksida (TBARS) yang terukur menggambarkan gagalnya mekanisme pertahanan antioksidan endogen dalam kehadiran radikal bebas yang berlebih (Balamurugan et al. 2008). Murugesh et al. (2005) menjelaskan bahwa parasetamol dalam dosis 
terapetik (250 mg/kgBB) dapat dimetabolisme dan didetoksifikasi oleh hati dengan cara glukuronidasi dan sulfasi sehingga dapat diekskresi melalui ginjal. Tetapi, ketika parasetamol sudah berada dalam dosis toksik, senyawa ini dikonversi ke dalam bentuk N-asetil-p-benzokuinonimina (NAPKI). Senyawa tersebut merupakan bentuk elektrofilik intermediet yang lebih toksik dan reaktif, hasil oksidasi kompleks enzim sitokrom P450. NAPKI secara cepat bereaksi dengan glutation (GSH) dan mengawali penghabisan $90 \%$ total GSH pada sel dan mitokondria, sehingga mengakibatkan kematian hepatoseluler dan disfungsi mitokondria. Interaksi NAPKI dan GSH membentuk konjugat GSH-acetaminophen, yang merupakan metabolit dengan kereaktifan yang lebih tinggi (Rezka et al. 2004). Selain itu Nagy et al. (2007) menjelaskan induksi parasetamol dosis tinggi menyebabkan kematian sel hepatosit secara apoptosis maupun nekrosis. Perbedaan dengan kelompok lain, kelompok normal $(\mathrm{N})$ tidak diberi perlakuan pencekokan parasetamol, tetapi dicekok akuades sebagai kontrol. Namun konsentrasi TBARS serum yang terukur mengalami peningkatatan sebesar $23,57 \%$ pada hari ke-18 menjadi $0,734 \pm 0,069 \mathrm{nmol} / \mathrm{mL}$. Peningkatan ini diduga disebabkan oleh kondisi stress oksidatif tikus akibat pencekokan akuades, yaitu stress elektron pada fosforilasi oksidatif membran dalam mitokondria menghasilkan jumlah anion peroksida $\left(\mathrm{O}_{2} \bullet^{-}\right)$yang tinggi sehingga meningkatkan peroksidasi lipid membran (Balamurugan et al. 2008). Tetapi, jika konsentrasi TBARS ketiga kelompok yang diinduksi parasetamol dibandingkan dengan kelompok normal, maka konsentrasi TBARS tidak berbeda nyata $\left(\mathrm{F}_{\text {hit }}<\mathrm{F}_{\alpha}\right)$. Artinya, pada penelitian ini, induksi parasetamol $500 \mathrm{mg} / \mathrm{kgBB}$ selama 17 hari belum mampu memberi pengaruh perusakan hati yang berarti. Hal ini diduga disebabkan oleh masih berperannya antioksidan endogen di dalam tubuh tikus terhadap NAPKI ataupun radikal bebas lainnya (Kaplan \& Pasce 2010). Oleh karena itu, induksi parasetamol tetap diteruskan hingga hari ke-34 untuk mempertegas pengaruh parasetamol 500 $\mathrm{mg} / \mathrm{kgBB}$ untuk meminimalisir pengaruh antioksidan endogen dalam menghambat peroksidasi lipid.

Percobaan dilanjutkan hingga hari ke-34 dengan perlakuan yang berbeda pada tiap kelompok. Kelompok normal (N) tetap dicekok akuades dan konsentrasi TBARS yang diperoleh menurun dari konsentrasi sebelumnya (sebesar
$2,21 \%$ ) menjadi $0,717 \pm 0,052 \mathrm{nmol} / \mathrm{mL}$. Penurunan ini diduga disebabkan oleh aktivitas pertahanan dari senyawa antioksidan endogen, seperti enzim katalase, superoksida (GPx), dan protein glutation tereduksi (GSH) terhadap radikal (Stockham \& Scott, 2008). Profil kadar TBARS merupakan acuan nilai konsentrasi TBARS bagi kelompok tikus lain sebagai kondisi normal.

Sampai tahap akhir perlakuan, kelompok kontrol negatif (KN) tetap diinduksi parasetamol. Hasil penelitian menunjukkan bahwa konsentrasi TBARS tetap meningkat sebesar $35,12 \%$, menjadi $1,335 \pm 0,035 \mathrm{nmol} / \mathrm{mL}$ seiring dengan kontinuitas induksi parasetamol. Hal ini diduga karena pada kelompok ini hanya diberi pakan standar, sehingga kurang cukup untuk mendapat antioksidan ataupun asupan nutrisi lain yang dapat menangkal radikal bebas ataupun regenerasi sel akibat induksi parasetamol.

Kontradiksi dari kelompok $\mathrm{KN}$ adalah kelompok kontrol positif (KP) dan kelompok jus buah delima (JUS). Tikus kelompok KP diinduksi Cursil 70 dosis $13,3 \mathrm{mg} / \mathrm{kgBB}$ pada hari ke-18 hingga ke-34. Cursil70 merupakan salah satu obat komersil yang mengandung ekstrak kurkumin dan silimarin yang berfungsi sebagai hepatoprotektor. Hasil penelitian menunjukkan bahwa konsentrasi TBARS serum menurun sebesar $8,14 \%$, yaitu menjadi $0,869 \pm 0,039 \mathrm{nmol} / \mathrm{mL}$. Penurunan $8,14 \%$ konsentrasi lipid peroksida ini tidak lepas dari aktivitas kurkumin dan silimarin. Sebagian besar senyawa kurkumin yang terserap termetabolisme menjadi glukuronidakurkumin dan glukuronida tetrakurkumin. Pulla dan Lokesh (1994) menyatakan bahwa kurkumin dapat menurunkan peroksidasi lipid pada mikrosom hati tikus, membran eritrosit, dan homogenat otak. Kandungan silimarin yang terdapat pada Cursil70 merupakan ekstrak terstandardisasi dari biji Silybum marianum L. (Gaertn). Hasil penelitian Heryani (2010), menunjukkan bahwa fraksi polifenol buah delima dosis 13,3 mg/kgBB, 100 $\mathrm{mg} / \mathrm{kgBB}, \quad 250 \mathrm{mg} / \mathrm{kgBB}$ dan $500 \mathrm{mg} / \mathrm{kgBB}$ menurunkan kadar lipid peroksida tikus yang dinduksi parasetamol secara berturut-turut sebesar $10,45 \%, 18,18 \%, 33,23 \%$ dan $41,84 \%$. Kelompok tikus yang diberi jus buah delima $500 \mathrm{mg} / \mathrm{kgBB}$ dari hari ke-18 hingga hari ke-34 menurunkan kadar lipid peroksida sebesar 54,78\%. Penurunan kadar lipid peroksida tersebut jauh lebih tinggi dibandingkan dengan penurunan kadar lipid peroksida dari kelompok KP yang menurunkan kadar lipid peroksida sebesar $8,14 \%$ dan dari 
polifenol buah delima (JUS) dengan dosis 500 $\mathrm{mg} / \mathrm{kgBB}$, yaitu $41,84 \%$.

Penurunan kadar lipid peroksida yang lebih tinggi tersebut selain disebabkan kandungan polifenol dalam buah delima juga ada tannin hydrolizable (seperti punikalin, pedunkulagin, punikalagin galik, dan ester asam elagik pada glukosa) yang juga berfungsi sebagai antioksidan yang akan munurunkan kadar lipid peroksida.

Jika jus buah delima dengan dosis 500 $\mathrm{mg} / \mathrm{kgBB}$ ini dikonsumsi oleh manusia (dengan bobot badan $70 \mathrm{~kg}$ ), maka setiap harinya kira-kira manusia harus mengkonsumsi $35 \mathrm{~g}$ bulir buah delima. Pengonsumsian bulir buah delima sebanyak itu tidak menyulitkan kita untuk mengonsumsinya. Dengan perkataan lain tidak diperlukan preparasi sampel yang tidak dapat dilakukan oleh maysrakat pada umumnya. 


\section{KESIMPULAN DAN SARAN \\ Kesimpulan}

Induksi parasetamol $500 \mathrm{mg} / \mathrm{kgBB}$ selama 17 atau 34 hari perlakuan meningkatkan konsentrasi lipid peroksida serum tikus berturut-turut sebesar $63,30 \%$ dan $120,66 \%$. Jus buah delima dosis 500 $\mathrm{mg} / \mathrm{kgBB}$ memiliki respon yang lebih tinggi dibandingkan Cursil70 (dosis 13,3 mg/kgBB) dalam menurunkan peroksidasi lipid serum tikus yang diinduksi parasetamol berturutturut sebesar $54,80 \%$ (untuk jus buah delima) dan $8,14 \%$. (untuk Cursil 70)

\section{Saran}

Perlu dilakukan penelitian lanjutan untuk menguji parameter hepatoproteksi lain, seperti aktivitas enzim ALT, AST, ALP, GGT, SOD, katalase, GPx, GSH, dan bilirubin. Ulangan perlakuan perlu diperbanyak untuk memperkecil nilai keragaman.

\section{DAFTAR PUSTAKA}

Al-Maiman SA, Ahmad D 2002. Change in physical and chemical properties during pomegranate (Punica granatum L.) fruit maturation. Food Chem 76: 437-441.

Anila L, Vijayalakshmi NR 2003. Antioxidant action of flavonoids from Mangifera indica and Emblica officinalis in hypercholesterolemic rats. Food Chem 83: 569-574.

AOAC [Association Official Analytical Chemistry] 1995. Official Methods of Analysis. $16^{\text {th }}$ Ed. Washington DC: Association Official Analytical Chemistry.

Balamurugan M, Parthasarathi K, Ranganathan LS, Cooper EL 2008. Hypothetical mode of action of earthworm extract with hepatoprotective and antioxidant properties. $J$ Zhejiang Univ Sci B 9: 141-147.

Gan S et al. 1980. Farmakologi dan Terapi. Ed ke-2. Jakarta: UI Pr.

Heryani, 2010 Aktivitas Fraksi Polifenol buah delima (Punica granatum. L) terhadap peroksidasi lipid darah tikus yang diinduksi parasetamol (Skripsi). Bogor FMIPA-IPB.
Kaplan LA, Pesces JA. 2010. Clinical Chemistry: Theory Analysis and Correlation. Ed ke-5. New York: Mosby.

Lavenia A. 2010. Penghambatan peroksidasi lipid oleh ekstrak kulit batang mahoni (Swietenia macrophylla) pada tikus hiperurisemia [Skripsi]. Bogor: Fakultas Matematika dan Ilmu Pengetahuan Alam, Institut Pertanian Bogor.

Lu F. 2006. Toksikologi Dasar: Asas, Organ sasaran, dan Penilaian Risiko. Nugroho, penerjemah. Jakarta: UI Pr. Terjemahan dari: Toxicology, Fundamentals, Target Organs, and Risk Assessment.

Muriel P, Garciapina T, Perez-Alvarez V, Murelle M. 1992. Silymarin protect against paracetamol-induced lipid peroxidation and liver damage. Drug Chem Toxicol 1: 163-171

Murugesh KS, Yeligar VC, Maiti BC, Maiti TK. 2005. Hepato protective and antioxidant role of Berberis tinctoria Lesch leaves on paracetamol induces hepatic damage in rats. IJPT 41: 64-69.

Myers RH, Milton J. 1991. A First Course In The Theory of Linear Statistical Models. Boston: PWS-KENT Pub.

Nagy G, et al. 2007. Acetaminophen induces ER dependent signaling in mouse liver. Arch Biochem and Biophysics 459: 273279.

Pulla RA, Lokesh BR. 1992. Studies on spice principles as antioxidants of rat liver microsomes. Mol Cell Biochem 111: 117 124

Reszka KJ et al. 2004. Acetaminophen stimulates the peroxidative metabolism of anthracyclines. Arch Biochemistry and Biophysics 427: 16-29.

Stockham SL, Scott MA. 2008. Fundamentals of Clinical Veterinary Pathology. Iowa: Iowa State University Pr.

Yagi K. 1994. Free Radical in Diagnostic Medicine. Armstrong D, editor. New York: Plenum Pr. 